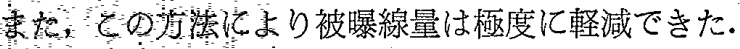

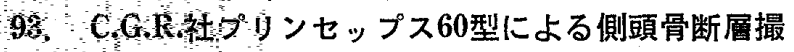
影の穃䧕

川㱦南漳川崎病院 中央エックス線室 䌽具處三郎・夏川 佳和・小南 幸雄 小林。淑高・伊藤 幸一・ ○坂野 健治

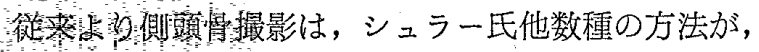

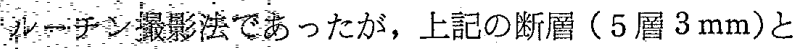

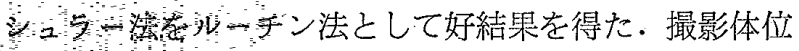

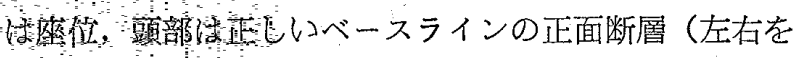

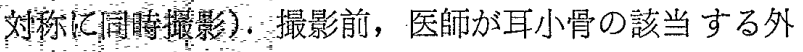

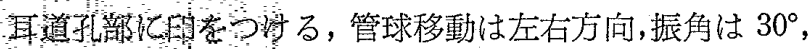

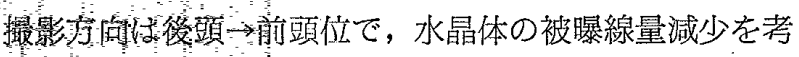

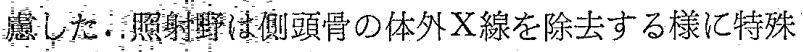

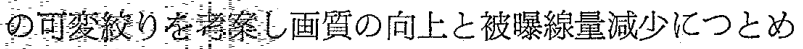

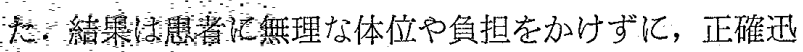

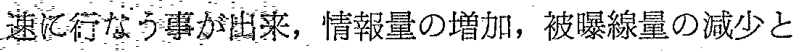

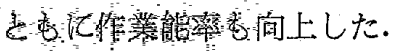

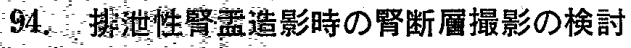

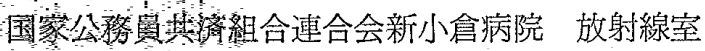
○獢迫 忠勝・柴田 清秀・伊東 忠志

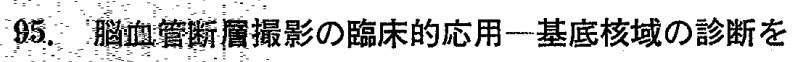
中icte

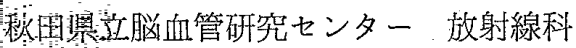
○整々信夫・相沢 康夫・庄司 安明

楾案体 レ\&ズ㧼動脈を脳血管断層撮影法で描出するた $20,2,30$ 当法之具体的条件を検討した。

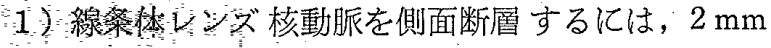

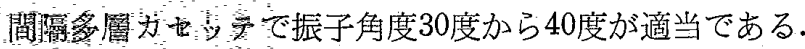

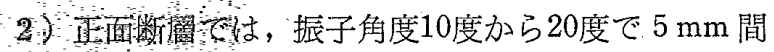

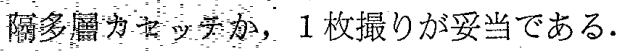

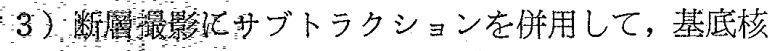

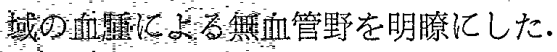

4)重靜脈相登一枚の写真に撮えるととを試みたが，

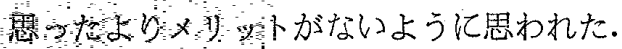

\section{6. 中耳，因再の断層撮影について}

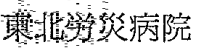

Q棌若仁·木田茂·神田真 南田 和一・八巻 昭一・高橋 良行

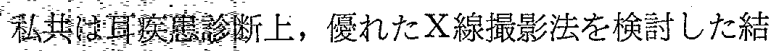

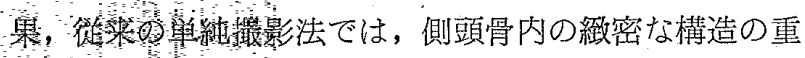

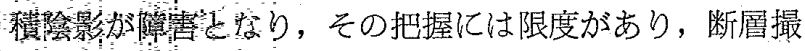

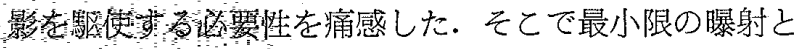

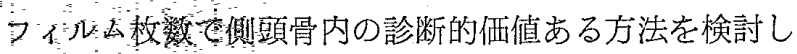

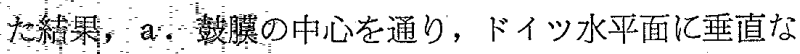

面 (frontal plane) と，b．鼓膜の中心を通り，前者よ り30〜35度後傾した面 (Antrotympanic plane) の $2 つ$ の面で断層撮影すれば，僅か 2 枚のフィルムで䁚頭骨内 の重要な器官, 部位を左右同時汇撮影できることがわか った.

97. 䂓関節における $2 \mathrm{~mm}$ 間隔同時多酋撮影の試み 東北歯科大学附属病院 歯科放射線科 菅野 忠夫 $\cdot$ 大坊 元二 $\cdot$ 照井 光治

[目的]

我々は第30回本学会で発表した基礎実験より，2 $\mathrm{mm}$ 間隔 5 層增感紙（75 kVp 設定）を使用するに当たり増 感紙の感度，画質，被暴線量について検討した。

〔結果〕

多層増感紙はFS に比し画質は劣っているとは言えな い、むしろ鮮鋭度は良好である．各層のバラッキは 1 層 と 5 層の差は $75 \mathrm{kVp}$ 亿おいて濃度差 0.3 であったが我 々の装置においては $70 \mathrm{kVp}$ の時バラッキは 0.2 の濃度 差であった。被曝線量は 1 枚撮影 5 回くり返しより $1 / 4$ に軽減できた．臨床においては顎関節部の断層像として 捉えられるのは中間部の約 $12 \mathrm{~mm}$ の範围であった。䋶 関節を撮影する場合は補助台より $20 \mathrm{~mm} \pm 2 \mathrm{~mm}$ から截 面を合水せる事により1 回の多層断層撮影で顎関節部を 現わす事ができる.

\section{Orbital axisis pneumography}

名古屋保健衛生大学病院

○沢田 武司・河合 恭嗣・鈴木 昇一

\section{[目的]}

眼䆟内気体注入法は必ず断層撮影する，乙の内，正側 断層の他に, 軸位断層撮影法 (orbital axisis pneumotomography) について検討した。

〔結果〕

1 、眼简周辺濃度を補正するために，軸位断層用補正 フィルターを作成した，使用材料は $10 \mathrm{~mm} \mathrm{Al}$ 亿相当す る paper filter を用いた. ての結果, 顔面輪郭が鮮明に 現出し，同時に被曝線量屯約 $20 \%$ 軽減出来た。

2. 本法の撮影体位は，逆軸位である．撮影方法は前 眼部から深部視束管までを同一層に断層撮影するため, 13度フィルム傾斜法を用いた。選択軌道はスパイラルで, $5 \mathrm{~mm}$ 間隔 6 枚撮影にした.

99. 狭角度による胸部斜面断層について

千葉県がんセンター

○佐藤 安男・毛利 快鲭・永井 義衛 木下富士美・小林 正木

[目的]

胸郭内腫瘍及びその気管，気管支りンパ系への転移の 